\title{
Riski ja tuotannon kehittäminen -Suomen IFCN-maitotilatarkastelu
}

\author{
Sami Ovaska ${ }^{1)}$, Timo Sipiläinen ${ }^{1)}$, Matti Ryhänen ${ }^{2)}$ ja Matti Ylätalo ${ }^{3)}$ \\ ${ }^{1)}$ MTT Taloustutkimus, Luutnantintie 13,00410 Helsinki, etunimi.sukunimi@mtt.fi \\ ${ }^{2)}$ Seinäjoen AMK, maa-ja metsätalouden yksikkö, Ilmajoentie 525, 60800 \\ Ilmajoki,matti.ryhanen@seamk.fi \\ ${ }^{3)}$ Taloustieteen laitos, PL 27,00014 Helsingin yliopisto, matti.ylatalo@helsinki.fi
}

\section{Tiivistelmä}

Suomen yhdentoista EU-jäsenyysvuoden aikana maatalousyrittäjät ovat joutuneet sopeutumaan jatkuvasti muuttuvaan toimintaympäristöön ja useiden politiikkauudistusten sarjaan. Vuoden 2003 kesäkuussa päästiin sopimukseen EU:n yhteisen maatalouspolitiikan uudistuksesta, jossa heikennettiin tukien ja tuotannon välistä yhteyttä. Suomen maataloustukijärjestelmään sisältyy myös muita tukia, joiden merkitys on maatalousyrittäjille usein selvästi pelkkiä CAP-tukia suurempi. Suomessa tukijärjestelmä kokonaisuutena on kehittymässä suuntaan, jossa tuotannon perusteella maksettavien tukien sijaan tuet maksetaan yhä enemmän peltohehtaarien kautta. Politiikkamuutokset aiheuttavat suuria haasteita erityisesti Etelä-Suomen maidontuotannolle, jossa maksetaan komission näkemyksen mukaan vain väliaikaista ja alenevaa litrakohtaista kansallista tuotantotukea. Tuottajahintojen ja tuotannon perusteella maksettavan tuen aleneminen yhdessä korkeiden investointitukien kanssa asettavat tilat haasteelliseen asemaan tulevaisuuden suunnittelussa.

Tukien riippuvuus poliittisista päätöksistä aiheuttaa maatalousyrittäjille institutionaalisen riskin, jonka merkitys on korostunut EU-jäsenyyden aikana. Suomessa vuotuiset sääolot saattavat aiheuttaa merkittäviä vaihteluja sadoissa, jolloin on kyse tuotantoriskistä. Eläinten sairastumiset saattavat aiheuttaa ennenaikaisia lypsylehmien poistoja. Tuotantopanosten ja tuotteiden hintoihin sekä markkinoiden epävarmuuteen liittyvä vaihtelu aiheuttaa viljelijälle puolestaan markkinariskin. Uuden teknologian käyttöönotto ja velkamäärän kasvu erityisesti tuotantoa laajennettaessa sisältävät myös omat rahoitus- ja teknologiset riskinsä.

Tutkimuksessa simuloitiin Etelä-Suomessa sijaitsevien alueelle tyypillisten 20 ja 40 lehmän IFCN- maitotilojen (International Farm Comparison Network) taloutta vuosille 2003-2012. Simulointi tehtiin stokastisella TIPI-CAL -mallilla (Technology Impact and Policy Impact Calculations), jonka antamien tulosten pohjalta arvioitiin politiikkamuutosten vaikutuksia tilojen talouteen ja tilojen tuotannon sopeuttamistarvetta. Simuloinnilla tutkittiin politiikkamuutosten ohella myös maidon ja ostorehujen hintavaihteluiden sekä maitotuotosten ja rehusatojen vaihteluiden merkitystä tilojen talouteen.

Tulosten mukaan tuotannon sopeuttamista tarvitaan korvaamaan alenevan tuen aiheuttamaa tilojen talouden heikkenemistä. Maitotuotosten ja satojen vuotuisvaihtelut aiheuttavat suurta vaihtelua tilojen taloudellisiin tuloksiin. Sen sijaan pelkkien hintavaihtelujen vaikutus tilojen talouteen on edellistä selvästi pienempi. Myös tuottavuuden kasvulla on suuri merkitys sopeutumisessa.

Avainsanat: riski, epävarmuus, maatalouspolitiikka, sopeutuminen, investoinnit 


\section{Johdanto}

Suomalaiset maatalousyrittäjät toimivat jatkuvasti muuttuvassa toimintaympäristössä. Euroopan unionin maatalouspolitiikkaa on uudistettu useassa eri vaiheessa pyrittäessä sovittamaan sitä entistä paremmin sisäisiin ja ulkoisiin muutospaineisiin. Vuoden 2003 kesäkuussa päästiin sopimukseen Euroopan unionin yhteisen maatalouspolitiikan uudistuksesta. Uudistuksessa höllennettiin tukien ja tuotannon välistä yhteyttä, millä pyritään eroon tuottamiseen kannustavasta tuesta. Nämä muutokset koskevat EU:n kokonaan rahoittamia CAP-tukia.

Viljan ja naudanlihan interventiohintoja on alennettu aiempina vuosina voimakkaasti, mitä on korvattu suoralla tuella. Vuonna 2003 päätetyt uudistukset vaikuttavat merkittävästi maidontuotantoon, sillä voin ja rasvattoman maitojauheen interventiohintoja alennetaan yhteensä $25 \%$ ja $15 \%$ vuosina 2004-2007. Tämä johtaa maidon tilityshinnan alenemiseen, jota korvataan maksamalla kiintiön perusteella maksettavaa palkkiota. Suomessa otetaan käyttöön tilatuen yhdistelmämalli vuonna 2006, jossa suurin osa EU:n maksamista CAP-tuista irrotetaan tuotannosta. Yhdistelmämallissa peltohehtaareille maksetaan alueellinen tasatuki ja kotieläintiloille lisäksi mahdollinen tilakohtainen lisäosa.

Maidon tuottajahinnan ja kansallisesti maksettavan maidon litrakohtaisen tuotantotuen aleneminen yhdessä EU -tukien tuotannosta irrottamisen ja investointitukien voimakkaan nousun kanssa asettavat maidontuottajat haasteelliseen tilanteeseen tuotannon kehittämisen ja investointien suhteen. Rakennusinvestoinnit ovat luonteeltaan pitkäikäisiä, peruuttamattomia ja suuruudeltaan huomattavia. Niiden tuotot kertyvät pitkällä ajanjaksolla ja ovat investointia seuraavina vuosina usein alhaiset. Rakentamis- ja rakennuksen käytön aikaiset kustannukset saattavat myös ylittyä suunnitellusta. Velasta joudutaan maksamaan korkoa ja lyhennyksiä pankille riippumatta siitä, millaiseksi tilan talous muodostuu. Oman pääoman suhteellinen väheneminen investoivalla tilalla vähentää oman pääoman "puskuria" huonoja aikoja vastaan. Maksuvalmius saattaa myös joutua koetukselle, jos eläinpaikkoja ei saada nopeasti täyteen tai kohdalle sattuu huono satovuosi.

Tukien riippuvuus poliittisista päätöksistä on esimerkki maatalousyrittäjän toimintaympäristöön sisältyvästä institutionaalisesta riskistä, jonka merkitys on korostunut EU-jäsenyyden aikana. Onnettomuus-, markkina- ja tuotantoriskit ovat maidontuotannossa myös läsnä. Uuden teknologian käyttöönotto ja velan kasvu erityisesti tuotantoa laajennettaessa sisältävät myös omat riskinsä. (ks. Hardaker ym. 2004). Suomalaiset maatalousyrittäjät kokevat institutionaalisen riskin markkinariskin ohella merkittävimmäksi maatalouden riskilähteeksi (Hirvi 2004, s. 25, Heikinmaa 2003, s. 153-154, Sonkkila 2002, s. 76). Suomalaisten viljelijöiden riskienhallintakeinoina korostuvat usein rahoitusstrategiat, kuten maksuvalmiuden ja vakavaraisuuden ylläpito. Myös tuotannon ja talouden suunnittelu ja tarkkailu ovat keskeisellä sijalla.

Tämän tutkimuksen tavoitteena on

1) selvittää EU:n maatalouspolitiikka- ja tukimuutosten sekä kansallisten tukimuutosten vaikutusta maitotilojen talouteen ja arvioida tilojen sopeutumistarvetta

2) tutkia tuotannon laajentamista ja panos-tuotos -suhteiden muutoksia sopeutumiskeinoina sekä niiden vaikutusta maitotilojen talouteen huomioiden tuotosten ja hintojen vaihtelusta aiheutuva riski.

\section{Aineisto ja menetelmät}

Suomi on kuulunut kansainväliseen maitotilojen vertailuverkostoon (IFCN, International Farm Comparison Network) vuodesta 2002 alkaen. Verkoston päätavoitteena on maittain vertailukelpoisten tuotto- ja kustannustietojen kerääminen, joiden perusteella verkosto tuottaa vuosittain vertailuraportin. Tämän tutkimuksen aineistona käytetään Etelä-Suomesta muodostettuja tyypillisiä 20 ja 40 lehmän maitotiloja yksityiskohtaisine tilatietoineen. Yhden tilan ja koko tilajoukon tutkimisen välimuotona voidaan pitää niin sanottua tyypillisten tai edustavien tilojen tarkastelua, jolla tarkoitetaan tarkasteltavan toimialan tunnusomaista yritystä (Pearce 1992, s. 373). Kansainvälisen maitotilavertailun puitteissa Suomesta on muodostettu yhteensä kuusi tyypillistä maitotilaa Päijät-Hämeestä, Vieremältä sekä Etelä- ja Keski-Pohjanmaan alueelta. Suomen tyypillisten maitotilojen tietoja on hyödynnetty kansainvälisessä maitotilavertailussa (Hemme ym. 2002, 2003, 2004, 2005) sekä kahdessa kotimaisessa vertailussa (Ovaska ym. 2004a, 2004b). Tässä tutkimuksessa käytettävän kahden tilan tärkeimmät ominaisuudet on esitetty taulukossa 1. 
Taulukko 1. Tutkimustilojen keskeiset ominaisuudet vuodelta 2003.

\begin{tabular}{lccc} 
& & PH20 & PH40 \\
\hline Tukialue & & $\mathrm{B}$ & $\mathrm{B}$ \\
Lehmiä & $\mathrm{kpl}$ & 20 & 40 \\
Maitokiintiö & tn & 175 & 401 \\
Peltoa käytössä & $\mathrm{ha}$ & 24 & 60 \\
Oma työ & $\mathrm{h} / \mathrm{v}$ & 4500 & 5000 \\
Vieras työ & $\mathrm{h} / \mathrm{v}$ & 0 & 500
\end{tabular}

Maatalous luonteeltaan biologis-taloudellinen systeemi, jossa pyritään taloudellisiin päämääriin biologisten tuotantoprosessien avulla. Maataloustuotannolle on tyypillistä Suomessa suuret vuotuiset satovaihtelut. Myös karjan maitotuotokset voivat vaihdella vuosittain sairastumisten tai lehmien ylimääräisten poistojen vuoksi. Samoin tuottaja- sekä ostopanoshinnat ovat vaihdelleet Suomen EUjäsenyyden aikana. Kuvattaessa maitotilan tuotantoa ja taloutta deterministisellä mallilla nämä tuotannon olennaiset piirteet eivät tule huomioiduiksi. Deterministisessä mallissa muuttujiin ei sisälly riskiä, jolloin malli tuottaa annetuilla lähtöarvoilla tulokseksi yhden määrätyn arvon. Stokastisessa mallissa on vähintään yksi riskiä sisältävä muuttuja. Tällöin tulokseksi saadaan yhden arvon sijaan arvojen jakauma. Tässä tutkimuksessa käytetään tutkimusmenetelmänä stokastista simulointia (ks. Hardaker ym. 2004, s. 157-181).

Maidontuottaja kykenee helposti laittamaan eri liikkeenjohdolliset vaihtoehdot paremmuusjärjestykseen esimerkiksi taloudellisten tunnuslukujen perusteella, jos riskiä ei huomioida. Riskin huomiointi vaikeuttaa valintaa. Tällöin eri vaihtoehdot joudutaan asettamaan paremmuusjärjestykseen tulosten jakaumien perusteella. Tilatason riskianalyysillä pyritään arvioimaan erilaisista strategioista aiheutuvien taloudellisten tulosten jakaumia liikkeenjohdollisen päätöksenteon tueksi (Richardson 2005).

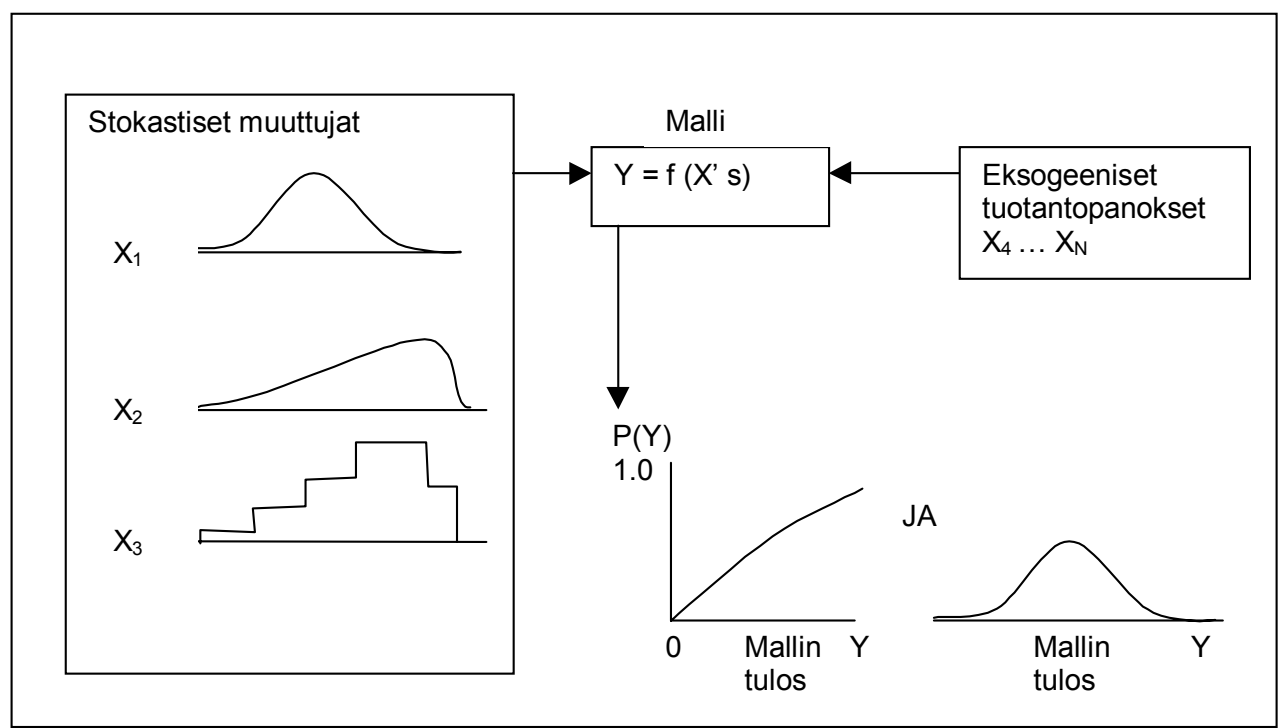

Kuva 1. Stokastisen simulointimallin kaaviokuva (Richardson 2005).

IFCN-verkostossa on käytössä tilatason simulointimalli (TIPI-CAL, Technology Impact and Policy Impact Calculations), jolla voidaan simuloida maitotilan reaali- ja rahaprosessia.. Kansainvälisissä maitotilavertailuissa mallia on käytetty tilatason taloudellisten tulosten deterministiseen sekä myös stokastiseen simulointiin 10 vuotta eteenpäin. Malli on rakennettu Excel-pohjaisena ja stokastisessa simuloinnissa käytetään Excelin lisäosana toimivaa Simetar (Simulation for Excel to Analyze Risk) ohjelmistoa (Richardson 2005). Tyypillisten maitotilojen tiedot koostuvat reaali- ja rahaprosessia kuvaavista yksityiskohtaisista tiedoista. Näitä ovat esimerkiksi sadot, pellonkäyttö, keskituotokset, koneet, rakennukset, työnkäyttö, myyntituotot, tuet ja kustannukset. Malli laskee näiden perusteella muun muassa tuloslaskelman, taseen, kassavirtalaskelman sekä maidon tuotantokustannuksen. Näiden lisäksi malli laskee useita taloudellisia tunnuslukuja, joista tärkeimpiä ovat maataloustulo, työtuntiansio ja pääoman tuotto (IFCN 2003). 
Maitotilan toimintaympäristöön liittyvistä riskeistä on tähän tutkimukseen sisällytetty hinta- ja tuotantoriskit. Maatalouspolitiikan muutoksiin liittyvä institutionaalinen riski sisältyy simulointiin erilaisina politiikkaskenaarioina. Hinta- ja tuotantoriskien huomiointi mallissa edellyttää syöttötiedoiksi myös tiedot 10 simulointijaksoa edeltävän vuoden toteutuneista hinnoista ja tuotoksista. Näiden 10 vuoden historiatietojen perusteella mallissa muodostetaan kaikille riskiä sisältäville stokastisille muuttujille jakaumat, jonka jälkeen mallilla tehdään yksi iteraatio. Tällä tarkoitetaan yhtä simulointia, joka tehdään poimimalla kaikille stokastisille muuttujille satunnaiset arvot niiden jakaumista. Tällöin tulokseksi saadaan yksi mahdollinen tulostieto, esimerkiksi maataloustulo, satunnaisilla stokastisten muuttujien arvoilla. Otanta jakaumista tehdään Latin Hypercube-menetelmällä, jolloin sata iteraatiota riittää luotettavan jakauman muodostamiseen valitusta mallin tuottamasta tulostiedosta, esimerkiksi maitotilan maataloustulosta. Tässä tutkimuksessa tuotostiedot perustuvat vuosien 1993-2002 ja hinnat 19952002 tietoihin. Seuraavat muuttujat ovat stokastisia: maidon, teuraslehmän, rehuviljan, maidon korvikerehun, kivennäisten ja täysrehun/tiivisteen hinnat sekä maitotuotokset, rehuvilja-, säilörehu-, heinäja laidunsadot ja lehmien uudistus- $\%$

Suomen tyypilliset IFCN-maitotilat on muodostettu ensimmäisen kerran vuonna 2002, joten niiltä ei ole saatavissa toteutuneita tuotostietoja 10 vuoden jaksolta. Tämän vuoksi tilojen vuotuisten tuotosvaihtelujen määrityksessä on käytetty apuna MTT Taloustutkimuksen kirjanpitotiloja. Kirjanpitotiloilta on määritetty vuosien 1993-2001 tuotokset prosentteina suhteessa vuoden 2002 tuotoksiin. Esimerkiksi vuonna 2002 Päijät-Hämeen 20 lehmän tilalla kaurasato oli $3500 \mathrm{~kg}$. Saman alueen maitokirjanpitotiloilla päästiin vuonna 2001 vain $84 \%$ :iin vuoden 2002 tasosta. Myös Päijät-Hämeen 20 lehmän tilalle on oletettu vastaava vaihtelu, jolloin vuoden 2001 kaurasadoksi oletetaan $0,84 * 3500 \mathrm{~kg}$ $=2940 \mathrm{~kg}$. Vuosien 1993-2002 tyypillisille tiloille toteutuneet hinnat on määritetty maa- ja metsätalousministeriön tietopalvelukeskuksen (TIKE) tilastohintojen avulla. Vuosien 1993 ja 1994 hintoina on käytetty vuoden 1995 hintoja, mikä johtuu ennen vuotta 1995 Suomessa harjoitetusta korkeahintajärjestelmään perustuvasta maatalouspolitiikasta. Tässä tutkimuksessa käytettävä tilojen simulointijakso kattaa vuodet 2004-2012 ja vuosi 2003 on toteutunut vuosi.

\section{Simulointivaihtoehdot}

Tilojen lähtökohdat politiikkamuutoksiin sopeutumiselle vaihtelevat merkittävästi, jolloin sopeutumistoimia ja niiden toteutusta joudutaan arvioimaan tilakohtaisesti. Toiselle tyypilliselle tilalle sopiva vaihtoehto ei välttämättä sovi toiselle. Taloudellisista tunnusluvuista tarkastellaan maataloustuloa, koko pääoman tuottoprosenttia ja maksuvalmiutta.

Perusmallissa ei tiloilla tehdä politiikkamuutoksista johtuvia sopeutumistoimia vaan tuotantostrategiana on harjoittaa lypsykarjataloutta vuosina 2003-2012 entisellään ilman suuria investointeja. Maitokiintiö sopeutetaan vastaamaan vuotuista tuotettua määrää ja käyttöajan lopussa koneet myydään sekä ne korvataan uusilla. Uusia rakennusinvestointeja tai merkittäviä rakennusten perusparannusinvestointeja ei tehdä, vaan tilan rakennusten kuntoa ylläpidetään vuotuisin kunnossapitomenoin.

Laajennusmallissa maatalouspolitiikan muutoksiin pyritään vastaamaan laajentamalla tuotantoa varovasti ja edullisesti vuonna 2004. Tällä pyritään hyödyntämään olemassa olevia koneita ja rakennuksia, ylläpitämään maatalouden tulotasoa ja pitämään työmäärän lisäys kohtuullisena. Uudisrakennusinvestointeja ei kuitenkaan tehdä, vaan lehmämäärää lisätään neljällä eläimellä $(20 \rightarrow 24$ ja $40 \rightarrow$ 44) vanhan navetan sisällä tehtävillä muutostöillä. Pienellä tilalla joudutaan muutostöiden vuoksi luopumaan neljän hiehon kasvatuksesta ja ostamaan ne tilan ulkopuolelta. Suuremman tilan navetassa hiehopaikkoja ei suoraan voida muuntaa lehmäpaikoiksi, vaan navetassa joudutaan tekemään uudet paikat neljälle lehmälle. Tämän kustannus on yhteensä 20000 euroa, johon saadaan investointiavustusta yhteensä $45 \%$. Rakentamalla neljälle lehmälle uudet paikat voidaan kaikki hiehot kasvattaa edelleen itse. Molemmilla tiloilla on hankittu aiempina vuosina hieman ylimääräisiä maitokiintiöitä, jolloin lehmäluvun lisäys ei edellytä kiintiön ostoa. Lisääntynyttä rehuntarvetta varten vuokrapeltoa hankitaan pienellä tilalla lisää 6 ha ja suuremmalla 10 ha. Näillä viljellään nurmisäilörehua. Eläinmäärän ja peltoalan lisäyksestä aiheutuva työmäärä lisäys $(200 \mathrm{~h})$ hoidetaan pienellä tilalla omalla työllä ja suuremmalla tilalla vieraan työvoiman käytön lisäyksellä. Lisääntynyt lehmämäärä voidaan hoitaa entisillä koneilla, jotka uusitaan niiden käyttöajan lopussa.

\section{Mallien laskentaoletukset}

Maidon tuottajahinnan oletetaan alenevan vuosina 2004-2007 yhteensä 15 \%. Vuodesta 2004 alkaen tiloille maksetaan maitopalkkiota ja vuodesta 2006 alkaen alueellista tasatukea ja tilakohtaista lisä- 
osaa. Tasatukena käytetään vuonna 2006 yhteensä 193 euroon/ha, josta se nousee vuonna 2011 yhteensä 201 euroon/ha. LFA-tuen kansallisen lisäosan oletetaan säilyvän vuosina 2004-2012 hehtaarilta $92 €$ :ssa. Myös ympäristötuen oletetaan säilyvän hehtaarilta 130 eurossa koko jaksolla. Ympäristötuen kansallisen lisäosan tasona vuosina 2006-2012 käytetään vuoden 2005 tasoa. Kansallisesti EteläSuomessa A- ja B-tukialueilla maksettava maidon lisähinta muuttuu vuosina 2004-2007 samassa suhteessa kuin maidon 141- tukivaltuudet. Tuki alenee erityisesti vuonna 2005, jolloin se alenee edellisen vuoden 5,4 sentistä 3,1 senttiin $/ \mathrm{kg}$. Tukea maksetaan vielä seuraavalla nelivuotiskaudella 2008-2011, jolla se alenee tasaisesti ja poistuu kokonaan 2012. Tuen alenemista ei kompensoida tiloille. Rehusadot vaihtelevat vuosittain, jolloin tilalle ostetaan huonona vuonna puuttuva rehu ja hyvänä vuonna ylimääräinen rehu myydään. Tuotantopanosten vuotuisina hintamuutoksina on käytetty apuna Tilastokeskuksen maatalouden tuotantovälineiden ostohintaindeksejä ja kuluttajahintaindeksiä sekä niiden keskimääräisiä muutoksia jaksolla 1995-2002 (Tilastokeskus 2003a,b). Kuluttajahintaindeksin mukaista 1,5\% vuotuisnousua käytetään kulutusmenoille ja pellonvuokrille. Koneiden ja rakennusten hinnat nousevat $2 \%$ vuodessa. Kiinteät kulut ja muuttuvat kustannukset nousevat $1 \%$ :n vuodessa ja työkustannus 2,5\%. Korkotason sekä lihan, eläinten ja maitokiintiön hinnat säilyvät vuoden 2003 tasolla koko jakson. Sadot ja karjan keskituotokset nousevat 1 \% vuodessa.

\section{Tulokset ja tulosten tarkastelu}

Kuvissa tulokset esitetään graafisesti sisältäen keskimääräisen tuloksen ohella prosenttipisteet 5,25 , 75 ja 95. Prosenttipisteillä kuvataan simuloinnin stokastisten muuttujien, kuten satojen ja keskituotosten, vaikutusta tilan tuloksiin. Jos esimerkiksi 5 prosenttipisteessä maataloustulo on 10000 euroa ja 95 prosenttipisteessä 20000 euroa, niin maataloustulo on $90 \%$ :n todennäköisyydellä välillä 10000-20 000 euroa. Tällöin myös alle 10000 euron tai yli 20000 euron maataloustulon todennäköisyys on molemmissa tapauksissa $5 \%$. Jos 25 prosenttipisteessä maataloustulo on puolestaan 15000 euroa ja 75 prosenttipisteessä 17500 euroa, maataloustulo on 50 \%:n todennäköisyydellä välillä 15000-17500 euroa. Maataloustulolla tarkoitetaan korvausta maatalousyrittäjäperheen maataloustyölle ja maatalouteen sijoitetulle omalle pääomalle. Se saadaan vähentämällä lypsykarjatalouden tuotoista kassamenot ja poistot. Koko pääoman tuottoprosentti saadaan vähentämällä tuotoista kaikki kustannukset vieraan pääoman korkomenoja sekä oman pääoman vaihtoehtokustannusta lukuun ottamatta ja suhteuttamalla jäännös lypsykarjatalouden pääoman määrään. Maksuvalmiuden riittävyyttä koko tilan tasolla kuvataan seuraavalla suhteella: tilan kassavirta (josta vähennetty puolisoiden tuloverot, jakson keskimääräiset investoinnit ja lainojen lyhennykset) / perheen elantomenot. Perheen elantomenoina vuonna 2004 on käytetty 20 lehmän tilalla 25000 euroa ja 40 lehmän tilalla 26000 euroa. Tunnusluku on hyvä jos suhde on yli 1,2 ja huono sen ollessa alle 0,8 . Näiden väliin jäävä suhde on keskinkertainen. Tunnusluvussa huomioidaan myös 20 lehmän tilan 4300 euron vuotuiset metsätulot ja 40 lehmän tilan 5800 euron metsätulot ja 1800 euron urakointitulot.

Perusmallin mukaan Päijät-Hämeen 20 lehmän tilalla maataloustulo laskee selvästi tarkastelujaksolla. Vuonna 2004 keskimääräinen maataloustulo on 28900 euroa. Maataloustuloa kertyy 90 \%:n todennäköisyydellä 20600-36300 euroa ja 50 \%:n todennäköisyydellä 25400-33000 euroa huomioitaessa hinta- ja tuotosvaihtelujen vaikutus tilan talouteen. Vuonna 2012 keskimääräinen maataloustulo laskee 17600 euroon ja ylittää 23400 euroa vain $5 \%$ :n todennäköisyydellä. Vuonna 2004 vastaavantasoinen maataloustulo saavutetaan sen sijaan $75 \%$ :n todennäköisyydellä. Koko pääoman tuottoprosentti laskee tarkastelujaksolla maataloustulon tavoin. Vuonna 2004 se on keskimäärin $-6 \%$ ja $90 \%$ :n todennäköisyydellä $-5 \%$ :n ja -10 \%:n välillä. Vuonna 2012 pääoman keskimääräinen tuottoprosentti laskee -16\%:iin. Tällöin parhaassa tapauksessa tilalla voidaan yltää vain $-14 \%$ :iin ja vain $5 \%$ :n todennäköisyydellä. Tilan maksuvalmius on parhaimmillaan vuonna 2004, jolloin se säilyy hyvänä 75 \%:n ja keskinkertaisena 25 \%:n todennäköisyydellä. Heikoimmillaan maksuvalmius on vuonna 2008, jolloin maidon hinnanlaskun jälkeen kustannusten noustessa ja kannattavuuden yhä heikentyessä joudutaan tekemään viimeinen lainanlyhennys (6900 euroa/v vuosina 2003-2008). Tällöin maksuvalmius on hyvä enää $14 \%$ :n ja keskinkertainen $86 \%$ :n todennäköisyydellä. Lainojen lyhennysten päättymisen jälkeen vuonna 2009 maksuvalmius paranee vuoden 2004 tasolle, kunnes kannattavuuden jatkuva aleneminen heikentää maksuvalmiuden jälleen vuonna 2012 vuoden 2008 tasolle. 

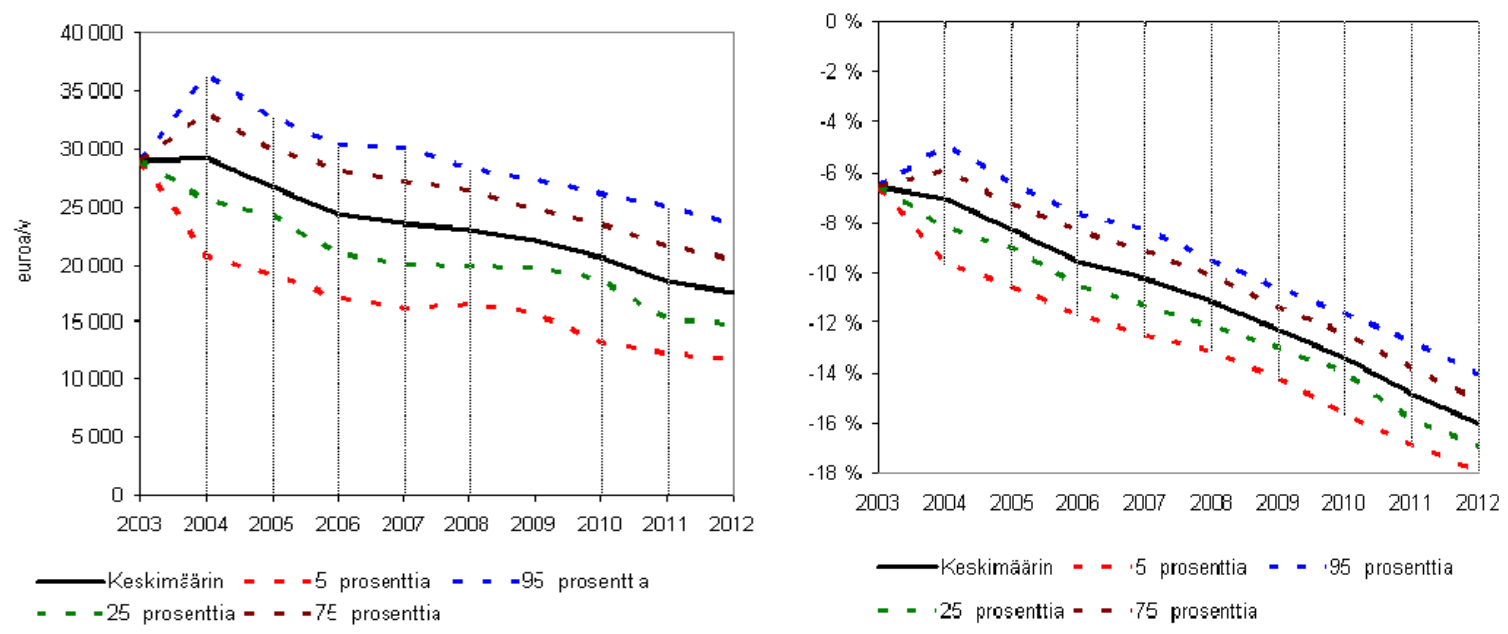

Kuva 2. Maataloustulo (vasen) ja koko pääoman tuotto-\% (oikea) perusmallissa 20 lehmän tilalla 2003-2012.
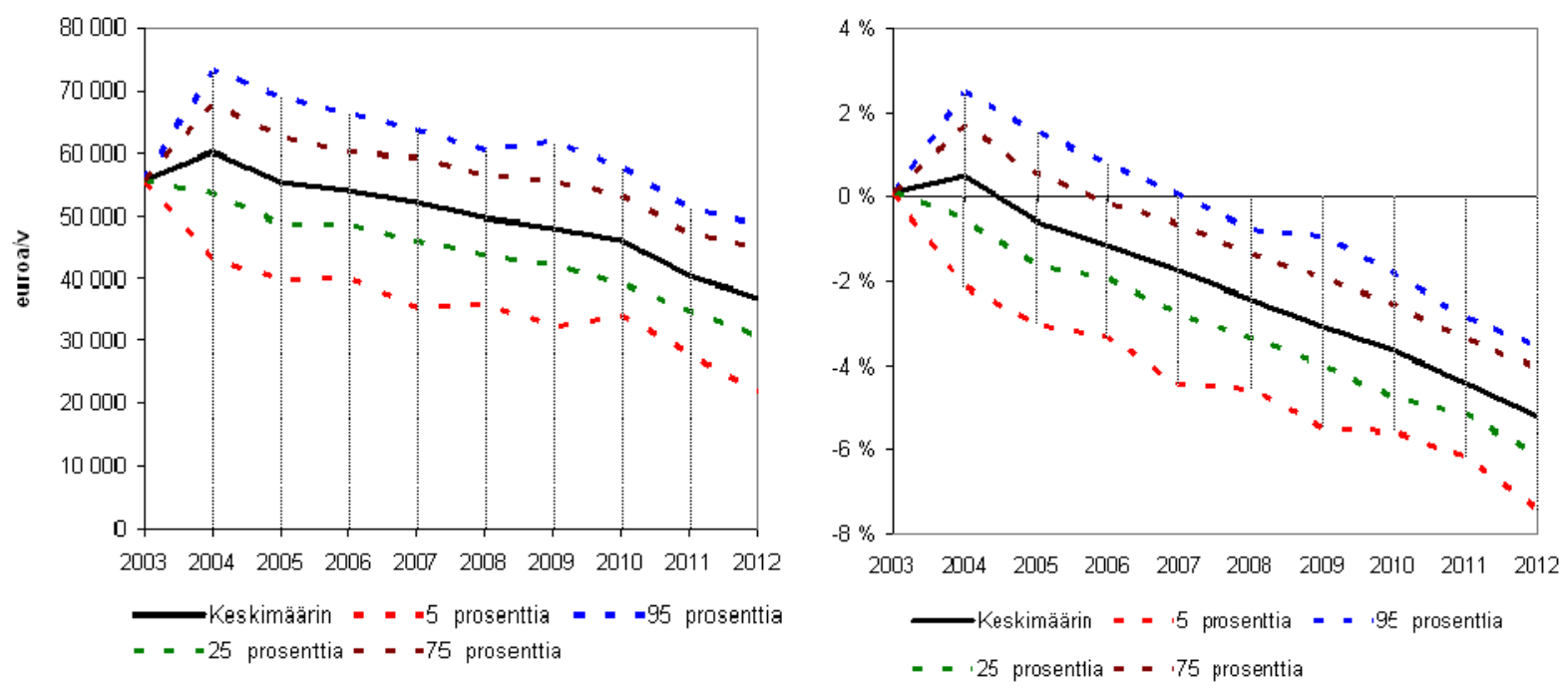

Kuva 3. Maataloustulo (vasen) ja koko pääoman tuotto-\% (oikea) perusmallissa 40 lehmän tilalla 2003-2012.

Myös Päijät-Hämeen 40 lehmän tilalla maataloustulo laskee selvästi tarkastelujaksolla. Vuonna 2004 keskimääräinen maataloustulo on 60200 euroa. Maataloustuloa kertyy $90 \%$ :n todennäköisyydellä 43000-72900 euroa ja 50 \%:n todennäköisyydellä 53400-67800 euroa. Vuonna 2012 keskimääräinen maataloustulo laskee 37000 euroon. Tällöin 48600 euron ylittäminen on yhtä todennäköistä kuin 72900 euron ylittäminen vuonna 2004. Samoin pääoman tuottoprosentti laskee tarkastelujaksolla maataloustulon tavoin. Vuonna 2004 se on keskimäärin lähellä nollaa ja $90 \%$ :n todennäköisyydellä -2 \%:n ja $2 \%$ :n välillä. Vuonna 2012 pääoman keskimääräinen tuottoprosentti laskee -5 \%:iin. Tällöin positiivisen tuoton saavuttaminen on enää hyvin epätodennäköistä, sillä tuotto parempi kuin $-4 \%$ vain 5:\%:n todennäköisyydellä. Tilan maksuvalmius on heikoimmillaan vuosina 2007-2008, jolloin maidon hinnanalennukset ovat toteutuneet, kustannukset nousevat ja vanhasta velasta maksetaan viimeiset lyhennykset (14900 euroa/v vuosina 2003-2008). Vuosina 2007-2008 saatetaan tilalla joutua maksuvalmiusongelmiin, sillä keskinkertaisen maksuvalmiuden todennäköisyys on $51 \%$ ja heikon noin 10 \%. Vuonna 2009 tilan maksuvalmius paranee selvästi. Lainojen lyhennysten päättymisen jälkeen vuonna 2009 maksuvalmius on hyvä 98 \%:n todennäköisyydellä, mutta alkaa 20 lehmän tilan tavoin heiketä uudelleen vuoteen 2012 tultaessa.

Edullisessa laajennusmallissa $(20 \rightarrow 24$ lehmään) Päijät-Hämeen 24 lehmän tilalla maataloustulon taso nousee laajennuksen vuoksi vuonna 2004, mutta lähtee selvään laskuun tarkastelujaksolla. Vuonna 2004 keskimääräinen maataloustulo nousee 39000 euroon. Maataloustuloa kertyy $90 \%$ :n todennäköisyydellä 28400-47100 euroa ja 50 \%:n todennäköisyydellä 35300-43600 euroa. Vuonna 2012 keskimääräinen maataloustulo laskee 28200 euroon ja ylittää 35600 euroa vain 5 \%:n todennäköisyydellä. 
Vuonna 2004 vastaavantasoinen maataloustulo saavutetaan sen sijaan $75 \%$ :n todennäköisyydellä. Myös koko pääoman tuottoprosentti nousee $-5 \%$ :iin vuonna 2004, mutta lähtee voimakkaaseen laskuun tämän jälkeen. Pienellä ja edullisella laajennuksella koko pääoman tuottoprosentti jää hyvin todennäköisesti edelleen negatiiviseksi, sillä vuonna 2004 se on parempi kuin $-2 \%$ vain $5 \%$ :n todennäköisyydellä. Vuonna 2012 keskimääräinen tuottoprosentti laskee $-13 \%$ :iin. Laajennuksen ansiosta tilalla suoriudutaan kuitenkin vanhan velan lyhennyksistä perusmallia paremmin, sillä maksuvalmius säilyy pääosin hyvänä koko tarkastelujaksolla. Heikoimpana vuonna 2008 keskinkertaisen maksuvalmiuden todennäköisyys ei kuitenkaan nouse kuin 9\%:iin.
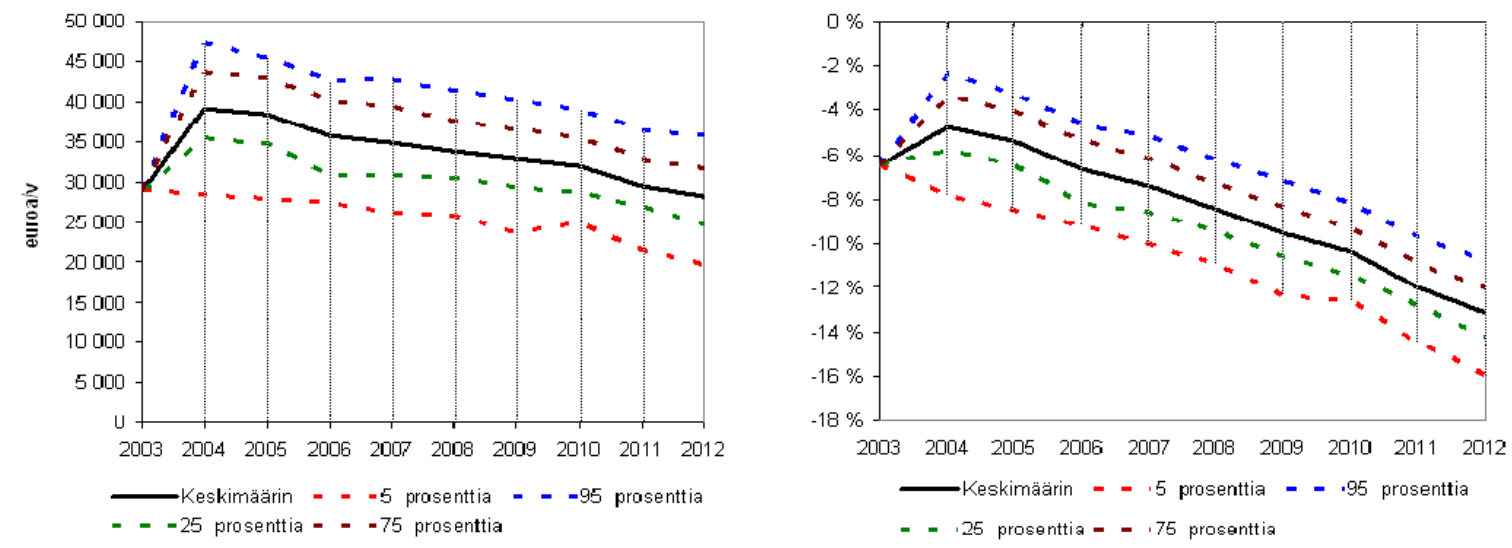

Kuva 4. Maataloustulo (vasen) ja koko pääoman tuotto-\% (oikea) edullisessa laajennusmallissa $(20 \rightarrow 24$ lehmään) vuosina 2003-2012.
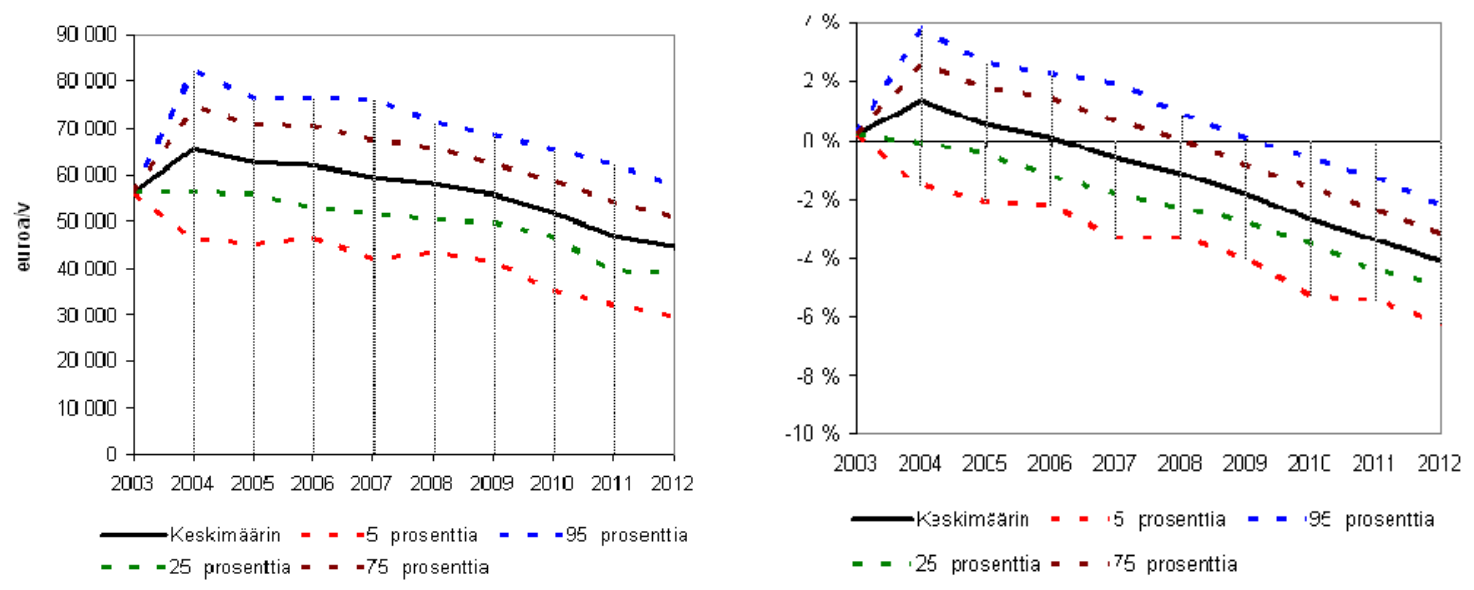

Kuva 5. Maataloustulo (vasen) ja koko pääoman tuottoprosentti (oikea) edullisessa laajennusmallissa ( $40 \rightarrow 44$ lehmään) vuosina 2003-2012.

Myös Päijät-Hämeen suuren tilan edullisessa laajennusmallissa $(40 \rightarrow 44$ lehmään) maataloustulon taso nousee laajennuksen vuoksi vuonna 2004, mutta lähtee selvään laskuun tarkastelujaksolla. Vuonna 2004 keskimääräinen maataloustulo nousee 65700 euroon. Maataloustuloa kertyy $90 \%$ :n todennäköisyydellä 42300-82200 euroa ja 50 \%:n todennäköisyydellä 56100-74000 euroa. Vuonna 2012 keskimääräinen maataloustulo laskee 44400 euroon ja ylittää 57400 euroa vain $5 \%$ :n todennäköisyydellä. Vuonna 2004 vastaavantasoinen maataloustulo saavutetaan sen sijaan $75 \%$ :n todennäköisyydellä. Myös koko pääoman keskimääräinen tuottoprosentti nousee $1 \%$ :iin vuonna 2004, mutta laskee nollaan vuonna 2006. Vuonna 2012 se laskee keskimäärin -4 \%:iin ja positiivisen tuoton saavuttaminen näyttää epätodennäköiseltä. Päijät-Hämeen suuren tilan investointikustannus on pientä tilaa suurempi (20000 euroa vrt. 0 euroa). Tästä huolimatta laajennus parantaa tilan taloutta niin, että heikon maksuvalmiuden todennäköisyys poistuu lähes kokonaan ja huonoimpina vuosina 2007-2008 hyvän maksuvalmiuden todennäköisyys kasvattaa osuuttaan noin $70 \%$.iin.

Kannattavuuden säilyminen molemmilla tiloilla edullisissa laajennusmalleissa edellyttäisi nousevaa nimellistä maataloustuloa kannattavuuden säilyttämiseksi. Kannattavuuden säilyminen tiloilla 
koko pääoman tuottoprosentilla mitattuna vuosina 2004-2012 edellyttäisi esimerkiksi 141-tuotantotuen säilymistä 3 sentissä/kg ja keskituotosten nousua 3 \% vuodessa.

\section{Johtopäätökset}

Maitotilojen kannattavuus näyttää heikentyvän lähitulevaisuudessa tämän tutkimuksen tyypillisillä IFCN-maitotiloilla. Lähivuosien kannattavuutta tutkimustiloilla alensivat erityisesti maidon tuottajahinnan lasku, kustannusten nousu sekä Etelä-Suomessa maksettavan maidon litrakohtaisen 141-tuen aleneminen ja poistuminen vuonna 2012 kokonaan. 20 lehmän tilalla perusmallissa keskimääräinen maataloustulo laski 28900 eurosta 17600 euroon ja 40 lehmän tilalla 60200 eurosta 37000 euroon vuosina 2004-2012. Hintoihin ja tuotoksiin liittyvän vaihtelun huomioinnilla oli suuri merkitys tilojen taloudellisiin tunnuslukuihin, jolloin tuloksia voidaan tulkita myös todennäköisyyksien avulla. Tämä voi tarjota lisäinformaatiota maatalousyrittäjän päätöksentekoa varten verrattaessa eri kehittämisvaihtoehtoja keskenään. Esimerkiksi 20 lehmän tilalla perusmallissa maataloustulo on melko todennäköisesti (90 \%) välillä 20600-36300 ja 40 lehmän tilalla välillä 43000-72900 euroa. Vuotuisten rehusatoja keskituotosvaihtelujen merkitys on tiloille selvästi pelkkää hintavaihtelua suurempi. Myös tilojen kannattavuus heikkeni tarkastelujaksolla. Koko pääoman keskimääräinen tuottoprosentti laski 20 lehmän tilalla vuosina 2003-2012 yhteensä $10 \%$-yksikköä -6 \%:sta -16\%:iin. Positiivisen tuottoprosentin saavuttaminen näyttää 20 lehmän tilalla hyvin epätodennäköiseltä jo vuonna 2004 ja näyttää tulevaisuudessa yhä epätodennäköisemmältä. 40 lehmän tilalla keskimääräinen koko pääoman tuottoprosentti on vuonna 2003 lähellä nollaa, mutta laskee seuraavina vuosina negatiiviseksi. Vuonna 2007 positiivisen tuottoprosentin todennäköisyys näyttää olevan enää $5 \%$, josta se laskee selvästi edelleen vuoteen 2012 tultaessa. Tilojen maksuvalmiudessa saattaa esiintyä ongelmia erityisesti vuosina 20072008, jolloin maidon hintaleikkaukset on tehty kokonaan ja molemmilla tiloilla maksetaan vanhojen velkojen viimeisiä lyhennyseriä. Tämän jälkeen maksuvalmius näyttä paranevan hieman molemmilla tiloilla, mutta maksuvalmiusongelmien todennäköisyys kasvaa hieman vuoteen 2012 tultaessa.

Edullisilla laajennusmalleilla tarkasteltiin pienen eläinmäärän $(+4)$ lisäyksen vaikutusta tilojen talouteen. Nämä vuonna 2004 tehdyt lisäykset nostivat maataloustuloa ja hieman koko pääoman tuottoprosenttia, mutta niillä ei pystytty ylläpitämään kannattavuutta. Esimerkiksi isolla tilalla $(40 \rightarrow 44$ lehmää) lisäys säilyttäisi keskimääräinen pääoman tuottoprosentin vain noin vuoden pidempään positiivisena verrattuna perusmalliin. Tilojen maksuvalmius parani edullisella laajennuksella erityisesti huonoimpina vuosina 2007-2008, jolloin velan lyhennyksistä pystyttiin selviytymään perusmallia paremmin. Edullisissa laajennusmalleissa olisi tutkimustiloilla kannattavuus säilynyt ennallaan tarkastelujaksolla, jos keskituotokset olisivat nousseet $3 \%$ vuodessa ja litrakohtaista 141-tukea olisi maksettu 3 senttiä/kg myös vuoden 2007 jälkeen vuosina 2008-2012. Tulosten mukaan tuotannon sopeuttamista tarvitaan korvaamaan alenevan tuen aiheuttamaa tilojen talouden heikkenemistä.

\section{Kirjallisuus}

Hardaker, J.B., Huirne, R.B.M., Anderson, J.R., \& Lien, G. 2004. Coping with risk in agriculture. 2 nd edition. Massachusetts: CABI Publishing. 332 s. ISBN 0-85199-831-3.

Heikinmaa, S. 2003. Käynnistystukea saaneiden viljelijöiden tilojen kannattavuus ja tulevaisuuden suunnitelmat. Teoksessa: Hirvijoki, M., Knuutila, K. \& Heikinmaa, S. 2003. Rahoitustukea saaneiden tilojen talous, suunnitelmien toteutuminen ja tulevaisuuden suunnitelmat. MTT Taloustutkimuksen selvityksiä 46. Helsinki: MTT Taloustutkimus. s. 115-161+13 liites.

Hemme, T. 2002. (ed.) Dairy report 2002. Status and prospects of typical dairy farms world-wide. Braunschweig: Federal Agricultural Research Centre (FAL). $141 \mathrm{~s}$.

Hemme, T. 2003. (ed.) Dairy report 2003. For a better understanding of dairy-farming world-wide. Braunschweig: Federal Agricultural Research Centre (FAL). $137 \mathrm{~s}$.

Hemme, T. 2004. (ed.) Dairy report 2004. For a better understanding of dairy-farming world-wide. Braunschweig: Federal Agricultural Research Centre (FAL). $152 \mathrm{~s}$.

Hemme, T. 2005. (ed.) Dairy report 2005. For a better understanding of dairy-farming world-wide. Braunschweig: Federal Agricultural Research Centre (FAL). 198 s.

Hirvi, T. 2004. Aktiivitilojen viljelijöiden mielipiteitä investointituesta ja nuorten viljelijöiden aloitustuesta. MTT Taloustutkimuksen selvityksiä 79. Helsinki: MTT Taloustutkimus. 60 s. +25 liites. 
IFCN 2003. International Farm Comparison Network. Methods: models. Viitattu 8.2.2005. Saatavissa internetistä: http://www.ifcnnetwork.org.

Ovaska, S., Sipiläinen, T. \& Ryhänen, M. 2004a. Suomen IFCN-maitotilat - Vuoden 2003 tulosten tarkastelu. MTT Taloustutkimuksen selvityksiä 74. Helsinki: MTT Taloustutkimus. 29 s.

Ovaska, S., Sipiläinen, T., Ryhänen, M. \& Ylätalo, M. 2004b. Maitotilojen tuotantotoiminta ja talous - Suomen, Ruotsin, Saksan ja Itävallan IFCN-tilojen vertailu. MTT Taloustutkimuksen selvityksiä 61. Helsinki: MTT Taloustutkimus. $54 \mathrm{~s}$.

Pearce, D. W. (ed.) 1992. The MIT dictionary of modern economics. 4 th edition. Massachusetts: MIT press. 486 s. ISBN 0-262-16132-X.

Richardson, J. W. 2005. Simulation for Applied Risk Management with Simetar. The Agricultural and Food Policy Center, Department of Agricultural Economics. Viitattu 13.1.2005. Saatavissa internetistä: http://www.afpc.tamu.edu/courses/622/downloads.php?dir=6.

Sonkkila, S. 2002. Farmers' decision-making on adjustment into the EU. Helsingin yliopiston talo-ustieteen laitoksen julkaisuja 34. Helsinki: Helsingin yliopisto. $160 \mathrm{~s}$.

Tilastokeskus 2003a. Maatalouden tuotantovälineiden ostohintaindeksi 1995-2003. Viitattu 17.12.2003. Saatavissa internetistä: http://tilastokeskus.fi/tk/hp/kui_maatal_1995i.xls.

Tilastokeskus 2003b. Kuluttajahintaindeksi 1995-2003. StatFin-tilastopalvelu. Viitattu 17.12.2003. Saatavissa internetistä: http://statfin.stat.fi/. 